\title{
Article \\ Food Safety and Sanitation Implementation Impasse on Adolescents in Kenyan High Schools
}

\author{
Csaba Bálint Illés ${ }^{1}\left(\mathbb{C}\right.$, Anna Dunay ${ }^{1, *}$, Charlotte Serrem ${ }^{2}\left(\mathbb{D}\right.$, Bridget Atubukha $^{3}\left(\mathbb{C}\right.$ and Kevin Serrem ${ }^{1}(\mathbb{C}$ \\ 1 Institute of Business Economics, Leadership and Management, Szent István University, \\ 2100 Gödöllő, Hungary; illes.balint.csaba@szie.hu (C.B.I.); kevin.serrem@phd.uni-szie.hu (K.S.) \\ 2 Department of Consumer Sciences, School of Agriculture and Biotechnology, University of Eldoret, \\ Eldoret 1125-30100, Kenya; charlottejes@gmail.com \\ 3 Faculty of Bioscience Engineering, Katholieke Universitiet Leuven, 3001 Leuven, Belgium; \\ kwamebree@gmail.com \\ * Correspondence: dunay.anna@szie.hu; Tel.: +36-30-522-000 (ext. 2180)
}

check for updates

Citation: Illés, C.B.; Dunay, A.; Serrem, C.; Atubukha, B.; Serrem, K. Food Safety and Sanitation Implementation Impasse on Adolescents in Kenyan High Schools. Int. J. Environ. Res. Public Health 2021, 18, 1304. https://doi.org/10.3390/ ijerph18031304

Academic Editors:

L'ubica Argalášová, Jana Jurkovičová and Michael Weitzman

Received: 9 January 2021

Accepted: 27 January 2021

Published: 1 February 202

Publisher's Note: MDPI stays neutral with regard to jurisdictional claims in published maps and institutional affiliations.

Copyright: (c) 2021 by the authors. Licensee MDPI, Basel, Switzerland. This article is an open access article distributed under the terms and conditions of the Creative Commons Attribution (CC BY) license (https:/ / creativecommons.org/licenses/by/ $4.0 /$ )

\begin{abstract}
The ability to combat food-borne illnesses in food facilities and institutional catering units require sufficient knowledge on food safety and sanitation standards by food producers and consumers. The aim of the study was to investigate the food safety and sanitation knowledge of food handlers in Kenyan high schools. A cross-sectional study was carried out among 204 food handlers in 50 schools. Questions about knowledge and practice toward food safety and sanitation were asked. Respondents were the most knowledgeable on food contamination (93\%), while participants were the least knowledgeable on the importance of protective attire when distributing foods to learners (50\%). One-way ANOVA revealed a significant difference between gender and food handlers' behavior and practice $(\mathrm{F}=19.886, \rho=0.00<0.05)$ as well as between job tenure and practice of food safety and sanitation $(F=17.874, \rho=0.00<0.05)$. Multiple regression analysis established that knowledge contributed to $44.1 \%$ of the behavior and practice of the food handlers. It is concluded that food handlers have a fair knowledge despite lack of training, motivation, and facilities to maintain quality standards. It is recommended that the Kenyan Government develop and implement guidelines through school feeding policy that would ensure that food safety and sanitation practices are implemented and utilized by Kenyan high schools.
\end{abstract}

Keywords: food handlers; knowledge; sanitation; safety; practice; high schools kitchens

\section{Introduction}

Food-borne diseases and outbreaks are crucial contributors to morbidity and mortality worldwide [1,2]. Every year, slightly over one-third of the entire population in developing countries is affected by food-borne diseases [3]. For instance, this is evident in West African countries such as Nigeria and Cameroon, which have had a reputation of not enforcing regulations and public ignorance on food safety, food fraud, and poor knowledge of food safety, awareness, and practice among consumers [4]. Likewise, in Asia, food-borne diseases pose the second greatest risk faced by the Chinese in daily life after earthquakes [5]. According to the European Food Safety Authority [6], approximately $48.7 \%$ of food-borne diseases were associated with the catering at both institutional and food service establishments, which should be a sector at the epitome of food hygiene and safety, setting trends for other industries to follow.

Education institutions such as primary and high schools' school feeding programs play a pivotal role in the fight against hunger and malnutrition. When properly designed, they have the potential to improve diets, nutrition knowledge, and practice for all beneficiaries, including service providers and students [7-9]. Emphasis on the implementation of food safety measures in school feeding programs are pegged on the vulnerability of schoolgoing children and adolescents to food-borne diseases due to their weaker immune systems 
compared to adults [10]. Coupled with inadequate infrastructure and paucity of food safety knowledge, food service providers such as food handlers have caused a surge in food-borne disease outbreaks in schools [11].

A significant role in food contamination has been attributed to human handling error by food handlers who are responsible for numerous outbreaks of food poisoning [12]. A study by Rowell [13] comparing high outbreak and non-outbreak facilities revealed that more than $65 \%$ of the meals associated with outbreaks were prepared or handled by employees who were infected, while 35\% was a result of bare hand contact on food. According to Basch [11], food worker practices can result in the direct and indirect transmission of pathogens through the contamination of food. Foods have a higher chance of being mishandled during preparation, processing, or storage than during consumption [14]. Some practices that may result in food contamination within food service environments include obtaining food from unsafe sources, the use of contaminated equipment, inadequate cooking of foods, and personal hygiene $[15,16]$. Additionally, improper holding times or inadequate temperatures during food processing especially for ready to eat foods (RTE), which are prepared in advance before consumption and subject to adverse temperature violations, lead to conditions that promote bacterial growth [17]. Appropriate food-handling practices and adequate personal hygiene minimize the transfer of pathogens from handlers to consumers [15]. According to Rowell [13], training is the best way to combat food safety challenges. As part of regulation, the Food and Drug Administration (FDA) ensures that managers are certified as food protection managers, during which they should be well equipped and knowledgeable with regard to food-borne disease prevention, principles of the Hazard Analysis and Critical Control Points (HACCP), and the requirements of the food code [18].

In developing countries such as Kenya, the public is exposed to food-borne pathogens due to changing lifestyles, globalization, changing microbial ecology, and reduced host immunity, which increases the risk of infection [19]. According to the World Health Organisation/ Food Agricultural Organisation [20], the main food-borne diseases are aflatoxin-poisoning gastroenteritis, cholera, dysentery, and brucellosis. For example, in the last 5 years, Kenya has experienced a surge in reported cases of cholera, both in households and institutions such as hospitals, universities, hotels, and restaurants, resulting in some fatalities [7].

Kenya being a developing and middle income country lacks documented guidelines through a school feeding policy on food safety and sanitation practices for use in schools, especially when administering food to school-going children and adolescents. Kenyan schools seem to provide feeding services to children and adolescents based on acquired knowledge and the availability of funds and resources, jeopardizing the health and wellbeing of the children and adolescents at a critical time of their lives, where a poor foundation of health will lead to lifetime complications. Therefore, the objective of this study was to evaluate the knowledge and practice of food handlers in Kenyan high schools.

\section{Materials and Methods}

A cross-sectional study was conducted in December 2019 and March 2020 to ascertain the level of knowledge and practice of food safety and sanitationof food handlers in Kenyan high school kitchens, catering for students aged 15 to 18 years. The target population included the catering manager and the cooks who were in charge of the kitchen. The study was conducted in eight counties, namely Nakuru, Uasin Gishu, Nandi, Kakamega, Nairobi, Kisumu, Likipia, and ElgeyoMarakwet, where 50 boarding high schools were selected for the study.

Sample size was determined by using a formula proposed by Mugenda and $\mathrm{Mu}$ genda [21].

$$
N=\frac{Z^{2} p(1-p)}{d^{2}}
$$

where 
$N=$ the desired sample size.

$Z=$ the $\mathrm{z}$ score at the required confidence level $=0.05(Z=1.96)$.

$p=$ the proportion in the target population estimated to have characteristics being measured.

$d=$ permissible marginal error (the level of statistical significance set at 0.005).

Purposive judgmental sampling was used by the researchers to select the 8 counties out of a total of 47 counties in the country, and 50 out of a total of 3000 high schools in Kenya for the study. This was carried out based on preliminary knowledge of the availability of boarding high schools in various counties. A catering manager from each of the 50 high schools was interviewed, and systematic random sampling was used to select particular cooks in various high school kitchens.

The questionnaire was divided into 5 sections. Section A addressed the socio-demographic details of the respondents, Section B addressed food handlers' training and HACCP awareness, Section $C$ included food safety knowledge, which comprised 3 constructs, transmission of food-borne diseases (with 8 items), personal hygiene (10 items), and food contamination ( 6 items). The total score for knowledge was 24 , and each scored 1 if the answer was right and 0 for a wrong answer or "I don't know". Food handlers were considered knowledgeable if they achieved a score of 50\% and above. Food handlers' food safety practices were assessed using 14 items. Participants were asked to score according to the frequency of these practices: $1=$ never; $2=$ occasionally; $3=$ sometimes; $4=$ often; $5=$ always. A pilot study was conducted on 10 food handlers, which led to a slight restructuring and rewording of the questionnaire. The reliability and validity of various sections of the research instrument was determined at a range of 0.63 to 0.79 .

Data analysis was carried out using SPSS software for windows version 23.0. Data were presented in mean and frequencies (\%). A one-way ANOVA test was used to establish relationships between demographic variables and knowledge and practice. A $p$-value of less than 0.005 was considered statistically significant. Multiple regression was used to assess the influence of Kenyan high school food handlers' knowledge in relation to their practice.

Ethical approval was granted by the National Commission for Science, Technology and Innovation, (NACOSTI) in Kenya permit number, NACOS-TI/P/1981086/28440. Participation in the study was voluntarily, and respondents were assured of anonymity and utmost confidentiality of the information provided.

\section{Results and Discussion}

There are two types of schools in Kenya, day schools and boarding schools; it is optional for the day schools to offer food to students, as students will consume the majority of their meals at home. On the other hand, it is mandatory for boarding schools to offer meals to students, as students consume the majority of their meals in schools. Additionally, all boarding schools in Kenya prepare their meals at the various institutions. As a precautionary measure, the authors chose to use boarding schools for the study, as they prepared food in the institutions.

\subsection{Socio Demographic Characteristics}

Table 1 shows the demographic characteristics of the respondents. The study featured 50 catering managers and 154 cooks. Of the 204 respondents, the majority $(76 \%)$ were men, while women were only $23 \%$. The greatest percentage $(81 \%)$ of the respondents were aged $36-40$ years. Only $47 \%$ had attained high school diplomas as their highest form of education. With respect to experience, most of the respondents $(60 \%)$ had over four years of experience as food handlers, and $59 \%$ had never previously worked in the food service industry. 
Table 1. Socio-demographic characteristics of food handlers in Kenyan secondary school kitchens.

\begin{tabular}{|c|c|c|c|}
\hline & & Frequency & Percent \\
\hline \multirow{3}{*}{ Personnel } & Managers & 50 & 24.5 \\
\hline & Cooks & 154 & 75.5 \\
\hline & Total & 204 & 100 \\
\hline \multirow{3}{*}{ Gender } & Male & 158 & 77.5 \\
\hline & Female & 46 & 22.5 \\
\hline & Total & 204 & 100 \\
\hline \multirow{6}{*}{ Age } & 25-35 years & 78 & 38.2 \\
\hline & $36-45$ years & 81 & 39.7 \\
\hline & $46-55$ years & 28 & 13.7 \\
\hline & $56-55$ years & 8 & 3.9 \\
\hline & over 65 years of age & 9 & 4.4 \\
\hline & Total & 204 & 100 \\
\hline \multirow{5}{*}{ Highest educational level } & primary school level & 93 & 45.6 \\
\hline & high school level & 96 & 47.1 \\
\hline & college & 14 & 6.9 \\
\hline & bachelors degree & 1 & 0.5 \\
\hline & Total & 204 & 100 \\
\hline \multirow{6}{*}{ Years as food handler } & less than one year & 15 & 7.4 \\
\hline & one & 34 & 16.7 \\
\hline & two & 16 & 7.8 \\
\hline & three & 16 & 7.8 \\
\hline & four & 123 & 60.3 \\
\hline & Total & 204 & 100 \\
\hline \multirow{3}{*}{ Work experience in food service } & yes & 84 & 41.2 \\
\hline & no & 120 & 58.8 \\
\hline & Total & 204 & 100 \\
\hline
\end{tabular}

\subsection{Training on Healthy Food Preparation, Food Safety, and Sanitation}

The study sought to establish whether food handlers underwent in-service training on healthy food preparation, food safety, and sanitation. The results in Table 2 show that slightly less than half of the respondents $47.5 \%$ (97) confirmed being trained. However, $52.5 \%$ (107) of the respondents mentioned they had never undergone any form of training on either healthy food preparation or food safety and sanitation. These findings were in sharp contrast to those of Sibanyoni and Tabit [10], whose study of South African schools revealed that $70 \%$ of the food handlers had received in-service training for safe food handling in their National School Nutrition Program (NSNP) food preparation facilities. Similarly, according to Ncube et al. [22], the majority (64\%) of the food handlers in Zimbabwe had not received basic food safety training, as food safety training was not mandatory in Zimbabwe as it is in Brazil, Malaysia, and European countries [23]. Proper and adequate training should be given to newly employed food handlers, without which they should not be allowed to handle food [24,25]. Adequate knowledge and experience in food safety is imperative for the effective formulation of food safety programs in food service establishments [26]. Moreover, food safety training should prioritize techniques that advocate for behavioral change and the obtainment of recommended food hygiene skills [27,28]. 
Table 2. Food handler training on healthy food preparation, food safety, and sanitation.

\begin{tabular}{cccccc}
\hline & Provision of Training & \multicolumn{3}{c}{ Frequency of Training } \\
\hline & Frequency & Percent & & Frequency & Percent \\
\hline Yes & 97 & 47.5 & Once every term & 26 & 12.7 \\
\hline No & 107 & 52.5 & Twice every term & 22 & 10.8 \\
\hline & & & Others & 49 & 24 \\
\hline Total & 204 & 100 & Total & 97 & 47.5 \\
\hline
\end{tabular}

\subsection{Types of Trainings}

Table 3 shows the food handlers' responses to the different types of training they have undergone. More than half $56.9 \%$ (116) of the respondents received training on personal hygiene. About $51.5 \%$ (105) received training on purchase procedures, while a similar number, $50.5 \%$ (103), did not receive training on pest control. Furthermore, 52.5\% (107) of the food handlers affirmed that they had received training on equipment cleaning procedures, whereas only $58.3 \%$ (119) of the food handlers had received training on food safety. A similar study conducted by Sibanyoni and Tabit [10] revealed the significance of an effective school feeding policy, as the South African school food handlers yielded much better results in comparison to the current study. With regard to personal hygiene, purchase procedure, and pest control, food handlers in that study achieved higher scores, $71.7 \%$, $73 \%$, and $63.3 \%$, respectively. Additionally, in equipment cleaning procedure, kitchen operation policy, and food safety, their study yielded $64.8 \%, 65.5 \%$, and $82.4 \%$ respectively. These further stem from the fact that in service, training plays a vital role in improving food handling practices and the attitudes of food handlers [1]. Inadequate training of food handlers has led to a lack of adequate food safety knowledge and food handling skills $[29,30]$.

Table 3. Types of training under taken by food handlers in Kenyan secondary school kitchens.

\begin{tabular}{|c|c|c|c|}
\hline$n=204$ & Yes/No & Frequency & Percent \\
\hline \multirow{2}{*}{ Personal hygiene } & yes & 116 & 56.9 \\
\hline & no & 88 & 43.1 \\
\hline \multirow{2}{*}{ Purchase procedures } & yes & 105 & 51.5 \\
\hline & no & 93 & 45.6 \\
\hline \multirow{2}{*}{ Pest control } & yes & 101 & 49.5 \\
\hline & no & 103 & 50.5 \\
\hline \multirow{2}{*}{ Equipment cleaning procedure } & yes & 107 & 52.5 \\
\hline & no & 97 & 47.5 \\
\hline \multirow{2}{*}{ Kitchen operations polices } & yes & 114 & 55.9 \\
\hline & no & 90 & 44.1 \\
\hline \multirow{2}{*}{ Food safety training } & yes & 119 & 58.3 \\
\hline & no & 85 & 41.7 \\
\hline \multirow{2}{*}{ Food allergy procedure } & yes & 103 & 50.5 \\
\hline & no & 101 & 49.5 \\
\hline \multirow{2}{*}{ Healthy cooking practices } & yes & 95 & 46.6 \\
\hline & no & 109 & 53.4 \\
\hline
\end{tabular}




\subsection{Knowledge and Utilization of Hazard Analysis and Critical Control Points (HACCP)}

Food handlers' knowledge on HACCP is shown in Table 4. Knowledge of HACCP is of utmost importance, as it is the basis for food safety and sanitation procedures in the kitchen, allowing food handlers to take necessary preventive measures. The study revealed that the majority of the food handlers $83.3 \%$ (170) did not have knowledge on HACCP. This was further affirmed, as $85.3 \%$ (174) of the food handlers mentioned that HACCP procedures were barely implemented in the various institutions in which they worked. These results resonate closely to those of Sibanyoni and Tabit [10], whose study indicated that $91.4 \%$ of the food handlers in South African schools did not know what HACCP was. Additionally, a similar percentage of respondents revealed that most of the institutions they worked for did not have an HACCP program in place. These findings were also similar to those of Ncube et al. [22], where a vast majority (96\%) of the food handlers in Zimbabwe neither received training nor practiced HACCP procedure. Furthermore, these results indicate that an overwhelming number of institutions neglect the use of important tools such as HACCP, hence highly pre-exposing learners to the risk of food-borne diseases [31]. HACCP is a requisite in the global food supply chain that minimizes the occurrence of negative effects of food safety to consumers [32,33]. According to de Cunha et al. [27], HACCP training should be provided every $6-12$ months and its adequacy evaluated regularly.

Table 4. Knowledge of Hazard Analysis and Critical Control Points (HACCP) by food handlers in Kenyan secondary school kitchens.

\begin{tabular}{cccc}
\hline Knowledge and Use of HACCP & & Frequency & Percent \\
\hline \multirow{2}{*}{ Food handlers' knowledge of HACCP } & yes & 34 & 16.7 \\
\cline { 2 - 4 } & no & 170 & 83.3 \\
\cline { 2 - 4 } & Total & 204 & 100 \\
\hline \multirow{2}{*}{ Use of HACCP program in school } & yes & 30 & 14.7 \\
\cline { 2 - 4 } & no & 174 & 85.3 \\
\cline { 2 - 4 } & Total & 204 & 100 \\
\hline
\end{tabular}

\subsection{Food Sanitation and Safety Knowledge}

The frequencies of knowledge scores for the three knowledge constructs (transmission of food-borne diseases, personal hygiene, and cross-contamination) are shown in Table 5 . It was observed that food handlers scored highly on questions pertaining to food contamination, with a mean of $80 \%$. Of concern was that nearly half of the respondents $(45 \%)$ lacked adequate knowledge that food prepared long in advance gave microbes time to grow. In contrast, a study by Thelwell-Reid [34] on the retraining of rural Jamaican food handlers observed that a majority of the population, $76 \%$, had adequate knowledge on the influence of time between the preparation of food and the growth of bacteria. Additionally, Nkhebenyane et al. [35] unveiled that the majority (64\%) of South African Hospice food handlers were aware of food poisoning risks involved with the early preparation of meals, while a further $68 \%$ were conversant with the danger of reheating food before consumption. A substantial percentage (63\%) of respondents disagreed with the fact that the HIV virus could be spread through food. On the contrary, Thelwell-Reid [34] reported that the majority, $89 \%$, of the participants in their study had the knowledge that HIV cannot be spread through the consumption of food. 
Table 5. The frequency of knowledge scores for food-borne diseases transmission, personal hygiene, and food contamination of food handlers in Kenyan high school kitchens (\% and the number of respondents in brackets).

\begin{tabular}{|c|c|c|c|c|}
\hline Knowledge Constructs & Transmission of Food-Borne Diseases Statements & Agree \% & Disagree \% & I Don't Know \% \\
\hline \multirow{9}{*}{$\begin{array}{l}\text { Transmission of } \\
\text { food-borne diseases }\end{array}$} & Well-cooked foods do not have germs & $68(139)$ & $32(65)$ & \\
\hline & Cholera can be spread through food & $77(156)$ & $24(48)$ & \\
\hline & $\begin{array}{l}\text { Healthy people can cause illness by carrying germs to } \\
\text { food }\end{array}$ & $67(137)$ & $33(67)$ & \\
\hline & $\begin{array}{l}\text { Vegetables and raw salads may be a media for } \\
\text { transmitting harmful microbes }\end{array}$ & $90(184)$ & $10(20)$ & \\
\hline & The HIV virus can be spread through food & $29(60)$ & $63(129)$ & $3(5)$ \\
\hline & $\begin{array}{l}\text { You can tell if food is unfit for consumption by smell, } \\
\text { taste, and look }\end{array}$ & $93(189)$ & $3(5)$ & $3(5)$ \\
\hline & $\begin{array}{l}\text { Food prepared too long in advance might give microbes } \\
\text { time to grow }\end{array}$ & $62(126)$ & $40(63)$ & $5(10)$ \\
\hline & Fresh meat always has microbes on the surface & $72(147)$ & $20(41)$ & $8(16)$ \\
\hline & Food transmission diseases & 74 & $32(65)$ & \\
\hline \multirow{13}{*}{$\begin{array}{l}\text { Personal health and } \\
\text { hygiene }\end{array}$} & Personal health and hygiene statements & Agree \% & Disagree\% & I don't know \% \\
\hline & $\begin{array}{l}\text { Hands can be washed with water alone before handling } \\
\text { raw meat }\end{array}$ & $17(35)$ & $80(164)$ & $3(5)$ \\
\hline & $\begin{array}{l}\text { You can prepare food with a wound on your hand if the } \\
\text { wound is covered with a bandage }\end{array}$ & $63(128)$ & $37(76)$ & \\
\hline & $\begin{array}{l}\text { It is not necessary to wash hands so as to handle food } \\
\text { that is already cooked }\end{array}$ & $15(31)$ & $85(173)$ & \\
\hline & $\begin{array}{l}\text { Hands should be properly washed after sneezing or } \\
\text { blowing your nose }\end{array}$ & $93(189)$ & $7(15)$ & \\
\hline & $\begin{array}{l}\text { Wearing gloves while handling food protects food } \\
\text { service staff from infection }\end{array}$ & $35(72)$ & $46(97)$ & $17(35)$ \\
\hline & $\begin{array}{l}\text { After using the bathroom, hands can be washed in the } \\
\text { kitchen sink }\end{array}$ & $37(75)$ & $63(129)$ & \\
\hline & $\begin{array}{l}\text { You should always change your foot wear when you } \\
\text { leave the kitchen and go out }\end{array}$ & $53(108)$ & $42(85)$ & $3(5)$ \\
\hline & $\begin{array}{c}\text { Do you always check the use-by dates of food before } \\
\text { using them? }\end{array}$ & $90(184)$ & $7(15)$ & $3(5)$ \\
\hline & $\begin{array}{l}\text { Do you wear a cap or chef's hat when touching or } \\
\text { distributing foods to learners? }\end{array}$ & $48(100)$ & $52(104)$ & \\
\hline & $\begin{array}{l}\text { Does the school provide you with an adequate } \\
\text { food-handling uniform? }\end{array}$ & $79(162)$ & $21(42)$ & \\
\hline & Personal health and hygiene & 70 & & \\
\hline & Food contamination statements & Agree \% & Disagree \% & I don't know \% \\
\hline \multirow{7}{*}{ Food contamination } & $\begin{array}{l}\text { Foods prepared with many steps increases handling } \\
\text { and the possibility of food contamination }\end{array}$ & $73(149)$ & $27(55)$ & \\
\hline & Food preparation surfaces can contaminate food & $83(169)$ & $17(35)$ & \\
\hline & $\begin{array}{l}\text { Food-borne diseases can result from storing raw meat } \\
\text { and cooked foods in the same refrigerator }\end{array}$ & $82(168)$ & $18(36)$ & \\
\hline & $\begin{array}{l}\text { Ready-to-eat foods can be prepared on the same cutting } \\
\text { boards that were used to prepare meat }\end{array}$ & $36(73)$ & $64(131)$ & \\
\hline & $\begin{array}{l}\text { Foods can be contaminated with microbes by coming in } \\
\text { to contact with unsafe foods }\end{array}$ & $93(189)$ & $8(15)$ & \\
\hline & $\begin{array}{c}\text { Meat cutting boards, slicers, and knives should always } \\
\text { be sterilized after use }\end{array}$ & $85(174)$ & $15(30)$ & \\
\hline & Food Contamination & 80 & & \\
\hline
\end{tabular}

With regard to personal health and hygiene, $63 \%$ of the respondents agreed that food handlers could handle food with injuries such as wounds as long as the wound was 
covered. This finding was similar to that of Nartey et al. [36], who reported that $67.5 \%$ of the catering staff in Ghanaian high schools agreed to the fact that handling food with wounds may be a potential cause for food-borne illnesses. Additionally, other scholars found much higher scores in similar studies conducted on the threats that wounds pose in cooking of food. They include Angelillo et al. [37] (99\%), Giritlioglu et al. [38] (86\%), and Tokuc et al. [39] (93.2\%). In relation to the importance of wearing protective attire while cooking and serving students, the study observed a low percentage (35\%) of participants. These findings were similar to those of Auad et al. [40], who after undertaking a similar study on Brazilian food trucks found that $97.7 \%$ of the food handlers only wore clean uniforms exclusively during food service to consumers, and none of them barely wore protective clothes such as aprons.

Furthermore, other knowledge items that scored low, $46 \%$ and $48 \%$, were wearing gloves while handling food protects food service staff from infection and the importance of wearing a cap or chef's hat when touching or distributing foods to learners, respectively. These findings differed from observations made by Nartey et al. [36], who found that 95\% of the caterers in high school wore protective clothes such as gloves, chef's hats, and aprons while cooking or during the service of food to learners. Likewise, Giritlioglu et al. [38] and Huang [41] reported similarly higher scores of knowledge among food handlers, 97.6\% and $82.9 \%$, respectively. On the other hand, a study by Kariuki and Orago [42] in Embu Municipality in Kenya found lower knowledge scores where $21 \%$ of the food handlers did not wear protective clothing while preparing food. Additionally, the protective clothing worn by over $30 \%$ of the participants was extremely dirty. According to Nkhebenyane et al. [35], only about $2 \%$ of the food handlers in South Africa utilized gloves fully, especially when dealing with unwrapped foods, this is despite their tracing on door contamination. Moreover, the study also established that $63 \%$ of respondents disagreed that it was acceptable to wash hands at the kitchen sink after visiting the bathroom or lavatory. These findings were consistent with those from a study by Thelwell-Reid [34] who reported that $93.1 \%$ of food handlers signified it was not allowed to wash dirty hands in the kitchen sink, as it would lead to the contamination of utensils or food items.

In relation to food contamination, of concern was a mere $36 \%$ of the respondents who were of the view that ready-to-eat food could be prepared on the same cutting boards used to prepare meat. These findings contradict those from a previous study by Santos et al. [43], where there were higher knowledge levels of hand washing after sneezing or nose blowing, which stood at $94 \%$. On the other hand, Nguyen et al. [44] found that almost the entire (98\%) food service consumer market in Hanoi was aware and cautious of the dangers of food contamination; hence, it heavily advocated for the separation of kitchen utensils such as tongs and knives used for raw and cooked food, respectively. A majority $(93 \%)$ of respondents were of the view that washing hands with soap in the bathroom was more hygienic, rather than in the kitchen sink, as it would lead to the contamination of either utensils or food stuff [39].

\subsection{Demographics in Relation to Knowledge Parameters}

Analysis of variance (ANOVA) was conducted to determine the correlation between food handlers' knowledge and food safety and sanitation (Table 6). In relation to gender, male food handlers were more knowledgeable on food transmission diseases and food contamination with average means of (2.833 and 2.761) and (2.683 and 2.633) for males and females, respectively. These findings were in line with those ofMohd Yusof et al. [45], who found out that male food handlers were more knowledgeable on food poisoning and contamination, after carrying out a similar study in a university in Malaysia. On the contrary, a study conducted by Auad et al. [40] revealed that female Brazilian food truck food handlers were more knowledgeable (8.25) compared to their male counterparts (6.97), while Abdul-Mutalib et al. [46] found no significant correlation between gender, education level, age, and work experience. In relation to age, there was a significant difference between food handlers' age and all knowledge constructs, which included 
food transmission diseases $(\mathrm{F}=5.188, \rho=0.001>0.05)$, personal health and hygiene $(\mathrm{F}=$ $6.824, \rho=0.00<0.05)$, and food contamination $(F=4.712, \rho=0.001<0.05)$ (Table 6). The study revealed that in all instances, knowledge decreased with increase in age. Earlier, Table 2 indicated that food handlers aged 25 to 35years were more knowledgeable on food transmission diseases (mean $=2.930$ ) than those aged 65 and above years of age (mean $=2.375$ ). Similar outcomes were observed for personal health and food contamination knowledge constructs, with means of 2.589 for 46 to 55years of age and 2.4 for 65 years and above. Auad et al. [40] reported contrasting results that food handlers aged 40 and above were the most knowledgeable (8.17) compared to their younger counterparts aged 26-40 (7.14), although the differences were not significant. Similarly, a study conducted by Adetunji et al. [47] on the personal hygiene of food handlers in Saudi Arabia revealed no significant differences in knowledge and age relationships, although the food handlers showed positive knowledge toward personal hygiene. Additionally, after carrying out a similar study on food handlers in Zimbabwe, Ncube et al. [22] found that the older the food handlers were, the less knowledgeable they were toward food safety, but on the other hand, the better the levels of attitude they had toward food safety.

Table 6. Demographic characteristics and level of food knowledge of food handlers in Kenyan high school kitchens.

\begin{tabular}{|c|c|c|c|c|c|c|c|c|c|c|}
\hline \multicolumn{2}{|c|}{ Demographics Characteristics } & \multicolumn{3}{|c|}{ Food Transmission Diseases } & \multicolumn{3}{|c|}{ Personal Health } & \multicolumn{3}{|c|}{ Food Contamination } \\
\hline & & \multirow{2}{*}{$\begin{array}{c}\begin{array}{c}\text { Descriptive } \\
\text { Statistics }\end{array} \\
\text { Mean (SD) }\end{array}$} & \multicolumn{2}{|c|}{ ANOVA } & \multirow{2}{*}{$\begin{array}{c}\begin{array}{c}\text { Descriptive } \\
\text { Statistics }\end{array} \\
\text { Mean (SD) }\end{array}$} & \multicolumn{2}{|c|}{ ANOVA } & \multirow{2}{*}{$\begin{array}{c}\begin{array}{c}\text { Descriptive } \\
\text { Statistics }\end{array} \\
\text { Mean (SD) }\end{array}$} & \multicolumn{2}{|c|}{ ANOVA } \\
\hline & & & $\mathbf{F}$ & Sig. & & F & Sig. & & F & Sig. \\
\hline \multirow{2}{*}{ Gender } & Female & $2.68(0.47)$ & 4.411 & 0.037 & $2.51(0.14)$ & 0.013 & 0.911 & $2.76(0.18)$ & 19.773 & 0.000 \\
\hline & Male & $2.83(0.14)$ & & & $2.51(0.13)$ & & & $2.63(0.18)$ & & \\
\hline \multirow{5}{*}{ Age } & $25-35$ years & $2.93(0.61)$ & 5.188 & 0.001 & $2.47(0.15)$ & 6.824 & 0.000 & $2.72(0.77)$ & 4.712 & 0.001 \\
\hline & $36-45$ years & $2.74(0.24)$ & & & $2.53(0.13)$ & & & $2.75(0.19)$ & & \\
\hline & $46-55$ years & $2.79(0.13)$ & & & $2.59(0.06)$ & & & $2.74(0.06)$ & & \\
\hline & $56-65$ years & $2.63(0.00)$ & & & $2.40(0.00)$ & & & $2.50(0.00)$ & & \\
\hline & Above 65 & $2.38(0.00)$ & & & $2.40(0.00)$ & & & $2.83(0.00)$ & & \\
\hline \multirow{4}{*}{ Education levels } & Primary & $2.71(0.20)$ & 2.910 & 0.036 & $2.49(0.12)$ & 3.206 & 0.024 & $2.74(0.18)$ & 0.884 & 0.450 \\
\hline & Secondary & $2.88(0.55)$ & & & $2.52(0.16)$ & & & $2.73(0.16)$ & & \\
\hline & College & $2.89(0.44)$ & & & $2.59(0.02)$ & & & $2.77(0.25)$ & & \\
\hline & Degree & $2.50(0.42)$ & & & $2.60(0.13)$ & & & $2.50(0.17)$ & & \\
\hline \multirow{5}{*}{ Experience } & $\begin{array}{c}\text { Less than one } \\
\text { year }\end{array}$ & $2.48(0.14)$ & 10.988 & 0.000 & $2.31(0.05)$ & 18.082 & 0.000 & $2.61(0.13)$ & 18.666 & 0.000 \\
\hline & One & $3.16(0.87)$ & & & $2.44(0.10)$ & & & $2.6(0.14)$ & & \\
\hline & Two & $2.83(0.14)$ & & & $2.63(0.06)$ & & & $2.59(0.11)$ & & \\
\hline & Three & $2.86(0.01)$ & & & $2.53(0.05)$ & & & $2.85(0.17)$ & & \\
\hline & Four & $2.72(0.19)$ & & & $2.53(0.14)$ & & & $2.79(0.16)$ & & \\
\hline
\end{tabular}

Note: Data presented as mean and Standard Deviation (S.D); One-way ANOVA used to test the correlation between demographic variables and knowledge.

ANOVA yielded statistical significance between the length of time the respondents had worked and their knowledge levels of food safety, food transmission diseases $(F=10.988$, $\rho=0.000<0.05)$, personal health $(F=18.082, \rho=0.000<0.05)$, and food contamination $(\mathrm{F}=18.666, \rho=0.000<0.05)$. The results revealed that in all parameters of knowledge, the longer the respondents worked, the more cautious they became about food safety. Similar findings were reiterated by Ncube et al. [22], who revealed that the majority of the food handlers (72\%) and (94\%) acquired more food safety knowledge and attitude skills, respectively, the longer they worked in a particular establishment. 


\subsection{Practice of Food Safety by Food Handlers}

Food handler behavior and practice are portrayed in Table 7 . The study observed a fairly adequate level (mean: 4.008) of food safety practices among food handlers in Kenyan schools. These findings mirror the results of Ko [48], who reported a practice average of 4.03 and 4.29 on food sanitary knowledge and behaviors respectively among university restaurant employees. Only about half of the respondents (2.882) used colorcoded chopping boards in the various kitchen facilities in which they worked. This outcome resonates with that of Ncube et al. [22], whereby the majority $(64 \%)$ of the food handlers were untrained and failed to use color-coded chopping boards in the kitchen, greatly increasing the risk of cross-contamination, especially for uncooked foods. On the other hand, a study conducted by Soares et al. [49] indicated that $79.1 \%$ of Brazilian school food handlers, who were familiar with HACCP procedures, as it was mandatory in the various facilities in which they worked, always ensured the use of color-coded chopping boards when preparing food. Furthermore, slightly above one-half (2.907) of the participants wore gloves in case of injury while cooking. The outcome of the study echoed that of Nkhebenyane et al. [35], whereby only $36 \%$ and $19 \%$ of trained and untrained food handlers respectively of South Africa's hospice facilities occasionally used gloves. The study mentioned that food handlers mostly wore gloves while touching and distributing unwrapped foods so as to curb the risk of cross-contamination. Additionally, a similar study by Ko [48] revealed that $99.6 \%$ of the food handlers (University restaurant employees) wore gloves when handling raw ready-to-eat foods and in case of wounds on their hands. The current study also revealed that slightly above one-half of the respondents used the threesink method while washing utensils. This was partly because the majority of the institutions that participated in the study were old institutions thatwere not modernized with adequate facilities to allow the use of the three-sink system. In addition, Abdullah [15] reported a similar outcome: slightly above one-half (3.79) of the food handlers in universities in Malaysia used the same method while washing utensils.

Table 7. Behavior and practice of food handlers in Kenyan high school kitchens.

\begin{tabular}{lll}
\hline \multicolumn{1}{c}{ Practice Items } & Mean & Std. Dev. \\
\hline First thing to do upon entering the kitchen is wash my hands. & 4.152 & 1.463 \\
\hline I always wear my tidy uniform prior to beginning work. & 4.064 & 1.652 \\
\hline I wash my hands when I touch the cooked food. & 4.598 & 1.094 \\
\hline I will perform at least one health check every year. & 4.652 & 0.932 \\
\hline I don't use cooking tools to taste the food. & 4.294 & 1.429 \\
\hline If I have wounds on my hand prior to coming to the kitchen, I will wear gloves. & 2.907 & 1.916 \\
\hline I use different chopping blocks to deal with the food materials. & 2.882 & 1.772 \\
\hline I dispose of any moldy food. & 4.750 & 0.916 \\
\hline If there are cracks on dishes, I will not use them. & 4.569 & 1.166 \\
\hline I completely disinfect the cutter and chopping block after work every day. & 4.230 & 1.283 \\
\hline I clean and dry the facility after work every day. & 4.417 & 1.360 \\
\hline I disinfect the work area regularly & 4.108 & 1.441 \\
\hline When I wash dishes, I use the three-sinks methods. & 2.848 & 1.748 \\
\hline I need to clean the drainage every day. & 3.642 & 4.008 \\
\hline Behavior and practice & 1.785 \\
\hline
\end{tabular}

\subsection{Demographics in Relation to Practice}

The study indicated a significant difference $(F=19.886, \rho=0.00<0.05)$ between the gender of food handlers and the behavior or practice toward food safety (Table 8 ). Male 
food handlers (4.078) were found to have a high level of practice of food safety in relation to their female counterparts (3.762). Mohd Yusof et al. [45], after carrying out similar studies on Malaysian University food handlers, found no relationship between gender and the practice of food safety in the institution. Other studies by various scholars revealed contradictory results, such as Sibanyoni and Tabit [10] and Nkhebenyane et al. [35], whose studies conducted in South Africa and Zimbabwe, respectively, both indicated that the majority of the female food handlers practiced food safety much more than their male counterparts. This was due to a large number offemale employees having been employees in various school kitchen facilities, as culturally such jobs were referred to as women's jobs.

Table 8. Demographics of food handlers in Kenyan high school kitchens in relation to practice.

\begin{tabular}{|c|c|c|c|c|c|}
\hline \multicolumn{2}{|c|}{ Demographics Characteristics } & \multicolumn{2}{|c|}{ Descriptive Statistics } & \multicolumn{2}{|c|}{ ANOVA } \\
\hline & & Mean & Std. Deviation & $\mathbf{F}$ & Sig. \\
\hline \multirow{2}{*}{ Gender } & Female & 3.762 & 0.409 & 19.886 & 0.000 \\
\hline & Male & 4.078 & 0.439 & & \\
\hline \multirow{5}{*}{ Age } & 25-35 years & 3.896 & 0.689 & 18.119 & 0.000 \\
\hline & $36-45$ years & 4.070 & 0.488 & & \\
\hline & $46-55$ years & 4.278 & 0.326 & & \\
\hline & $56-65$ years & 3.145 & 0.000 & & \\
\hline & Above 65 & 2.400 & 0.000 & & \\
\hline \multirow{4}{*}{ Education levels } & Primary & 4.101 & 0.410 & 9.543 & 0.000 \\
\hline & Secondary & 3.931 & 0.436 & & \\
\hline & College & 4.051 & 0.214 & & \\
\hline & Degree & 2.143 & 0.295 & & \\
\hline \multirow{5}{*}{ Experience } & Less than one year & 3.931 & 0.295 & 17.874 & 0.000 \\
\hline & One & 3.521 & 0.583 & & \\
\hline & Two & 4.067 & 0.227 & & \\
\hline & Three & 3.987 & 0.487 & & \\
\hline & Four & 4.141 & 0.313 & & \\
\hline
\end{tabular}

Note: Data presented as Mean and Std. deviation; One-way ANOVA used to test the correlation between demographic variables and practice.

The study also highlighted a significant difference $(F=18.119, \rho=0.00<0.05)$ between respondents' age and practice of food safety and sanitation, further stating the older category 56-65 years of food handlers most likely (4.278) to practice food safety and sanitation. The length of time spent in a particular job combined with the repetitive tasks performed is the prerequisite of experience in a particular career. Similar sentiments were echoed by Sibanyoni and Tabit [10] after carrying out similar studies on food handlers, who found that there was a high significance between age or work experience of the food handler, implying that the longer the food handlers worked, the more they observed hygienic practices. On the contrary, Mohd Yusof et al. [45] failed to find any significant differences between the ages and work experiences of the Malaysian food handlers with knowledge, attitude, and practice.

The study also realized significant differences $(F=9.543, \rho=0.00<0.05)$ between higher education levels and practice of food safety and sanitation, as food handlers who attended technical colleges (4.051) best practiced food safety and sanitation. This outcome also echoed that of Mohd Yusof et al. [45], who concurrently carried out research on both food handlers and dietetics students at the University of Malaysia. The study found out that the dietetics students had better knowledge and practice on comparison to the food handlers; this was attributed to the fact that they were better educated and had 
better education levels. Furthermore, various other scholars are in agreement with this finding. According to Soares et al. [49] and Abdullah [15], there is a common consensus that generally, the majority of the food handlers have lower levels of education, with the majority having finished high school. Despite this, a food handler with any form or level of education has a higher perception of knowledge and practice in comparison to those without any formal education.

\subsection{Multiple Regression on the Influence of Knowledge Parameters and Practice}

The results of Table 9 reveal the influence that the constructs of knowledge have on the practice of food safety and sanitation. The results indicate that the standardized coefficient beta and $p$-value of knowledge on food contamination were positive and significant (beta $=0.152, p<0.05)$. Therefore, a unit increase in knowledge on food contamination results is an improvement in behavior and practice by 0.152 units. The effect of knowledge on food contamination is shown by the t-test value of 2.768 , which implies that the effect of knowledge on food contamination surpasses that of the error. It was also observed that food handlers' knowledge on food transmission diseases had a coefficient of estimate that was significant based on $\beta 4=0.526$ ( $p$-value $=0.000$, which is less than $\alpha=0.05$ ). Therefore, units increase in food handlers' knowledge on food transmission diseases results in an improvement in behavior and practice by 0.526 units. The effect of food handlers knowledge on food transmission diseases is shown by the t-test value of 9.367 , which implies that the effect of food handlers' knowledge of food contamination surpasses that of the error. Generally, the findings indicate that the independent variable knowledge (whose constructs included knowledge on personal health, knowledge on food contamination, and knowledge on food transmission diseases) contributed up to $44.1 \%$ of the variation in behavior and practice of the food handlers, as explained by $\mathrm{R} 2$ of 0.441 , which revealed the adequacy of the model as a good prediction. Furthermore, Table 9 shows that the F-value of 39.235 with a $p$-value of 0.00 was significant at $5 \%$, indicating that the overall regression model is significant; hence, the joint contribution of the independent variables was significant in predicting behavior and practice.

Table 9. Multiple regression on the influence of knowledge on practice of food safety and sanitation.

\begin{tabular}{|c|c|c|c|c|c|}
\hline \multirow[t]{2}{*}{ Variables } & \multicolumn{2}{|c|}{ Unstandardized Coefficients } & \multicolumn{3}{|c|}{ Standardized Coefficients } \\
\hline & B & Std. Error & Beta & $\mathbf{t}$ & Sig. \\
\hline (Constant) & -1.047 & 0.825 & & -1.269 & 0.206 \\
\hline Personal health & -0.368 & 0.088 & -0.226 & -4.197 & 0.000 \\
\hline Food contamination & 0.753 & 0.272 & 0.152 & 2.768 & 0.006 \\
\hline Food transmission diseases & 0.827 & 0.088 & 0.526 & 9.376 & 0.000 \\
\hline \multicolumn{6}{|c|}{ Model Summary Statistics } \\
\hline \multicolumn{6}{|c|}{0.664} \\
\hline \multicolumn{6}{|l|}{ R Square } \\
\hline Adjusted R Square & \multicolumn{4}{|c|}{ Adjusted R Square } & \\
\hline \multicolumn{6}{|c|}{ Model Fitness Statistics } \\
\hline \multicolumn{6}{|c|}{39.235} \\
\hline Sig. & 0.000 & & & & \\
\hline \multicolumn{6}{|c|}{ a Dependent Variable: behavior and practice } \\
\hline
\end{tabular}

Note: Multiple regressions; demonstrate correlation on both knowledge and practice.

\section{Conclusions}

Kenyan's high school food handlers possess fairly adequate knowledge on food contamination and fairly low knowledge levels on personal health hygiene and the transmission of food-borne diseases. More than half of the study participants have never received 
any form of training or refresher courses on food safety and sanitation, while almost none of the participants know what Hazard Analysis Critical Control Point (HACCP) is. A majority of the respondents admit that none of the kitchen facilities they work for carry out HACCP procedures, hence compromising the health and safety of high school student by increasing susceptibility to food-borne illnesses.

\section{Recommendation}

Kenya requires documented guidelines as school feeding policy that are sustainable and at the same time all-inclusive. It is paramount that food handlers in Kenyan schools receive regular training sessions and for the professionals to receive regular refresher courses on food safety and sanitation, as it is evident from the study that knowledge of food safety and sanitation has a substantial impact on practice, further implying that an increase in knowledge will most likely increase the level of practice.

Additionally, the Hazard Analysis Critical Control Points (HACCP) should be uniformly implemented across all commercial institutional kitchens so as to ensure high surveillance of food through the various stages the food has go through while processing. Processes include temperature control, cross-contamination, proper cooking of foods, and deterioration (pathogens found in food).

Additionally, the policy could be emulated or incorporated by the wider East Africa member states as they face similar challenges. The authors should discuss the results and how they can be interpreted from the perspective of previous studies and of the working hypotheses. The findings and their implications should be discussed in the broadest context possible. Future research directions may also be highlighted.

Author Contributions: Conceptualization, C.B.I., K.S. and C.S.; methodology, C.B.I., K.S. and C.S.; software, K.S., B.A.; validation, C.B.I., K.S. and C.S.; formal analysis, C.B.I., K.S. and C.S.; investigation, K.S., C.S. and B.A.; resources, K.S., C.S. and B.A.; data curation, K.S. and A.D.; writing-original draft preparation, C.B.I., K.S. and A.D.; writing-review and editing, C.B.I., K.S. and A.D.; visualization, K.S. and A.D.; supervision, C.B.I. and A.D.; project administration, C.B.I. and A.D.; funding acquisition, C.B.I. All authors have read and agreed to the published version of the manuscript.

Funding: This research received no external funding.

Institutional Review Board Statement: The study was conducted according to the guidelines of the declaration of Helsinki, and approved by the Institutional Review board of the National Commission for Science, Technology and Innovation in KenyaBottom of Form (NACOSTI) (NACOS$\mathrm{TI} / \mathrm{P} / 1981086 / 28440,2 / 12 / 2019)$.

Informed Consent Statement: Informed consent was obtained from all subjects involved in the study.

Data Availability Statement: The data presented in this study are available on request from the corresponding author. The data are not publicly available as respondents were promised anonymity.

Conflicts of Interest: The authors declare no conflict of interest.

\section{References}

1. McIntyre, L.; Vallaster, L.; Wilcott, L.; Henderson, S.B.; Kosatsky, T. Evaluation of food safety knowledge, attitudes and selfreported hand washing practices in FOODSAFE trained and untrained food handlers in British Columbia, Canada. Food Control. 2013, 30, 150-156. [CrossRef]

2. Flint-Garcia, S.A.; Thuillet, A.C.; Yu, J.; Pressoir, G.; Romero, S.M.; Mitchell, S.E.; Doebley, J.; Kresovich, S.; Goodman, M.M.; Buckler, E.S. Maize association population: A high-resolution platform for quantitative trait locus dissection. Plant. J. 2005, 44, 1054-1064. [CrossRef]

3. World Health Organization (WHO). World health statistics. Defin. Indic 2007, 79-86. Available online: https://www.who.int/ whosis/whostat2007/en/ (accessed on 31 January 2021).

4. Odeyemi, O.A.; Sani, N.A.; Obadina, A.O.; Saba, C.K.S.; Bamidele, F.A.; Abughoush, M.; Asghar, A.; Dongmo, F.F.D.; Macer, D.; Aberoumand, A. Food safety knowledge, attitudes and practices among consumers in developing countries: An international survey. Food Res. Int. 2019, 116, 1386-1390. [CrossRef] [PubMed]

5. Grace, D. Food safety in low and middle income countries. Int. J. Environ. Res. Public Health 2015, 12, 10490-10507. [CrossRef] [PubMed] 
6. Scientific Report of EFSA. The Community Summary Report on trends and sources of zoonoses, zoonotic agents and food-borne outbreaks in the European Union in 2008. EFSA J. 2010, 8, 20-45. [CrossRef]

7. World Health Organization. Global Status Report on Noncommunicable Diseases 2014, Attaining the Nine Global Noncommunicable Diseases Targets: A Shared Responsibility; World Health Organization: Geneva, Switzerland, 2014; ISBN 9789241564854.

8. Szakály, Z.; Kontor, E.; Kovács, S.; Popp, J.; Pető, K.; Polereczki, Z. Adaptation of the Food Choice Questionnaire: The case of Hungary. Br. Food J. 2018, 120, 1474-1488. [CrossRef]

9. Szakály, Z.; Kovács, B.; Szakály, M.; Nagy-Pető, D.T.; Gál, T.; Soós, M. Examination of the eating behavior of the hungarian population based on the tfeq-r21 model. Nutrients 2020, 12, 3514. [CrossRef]

10. Sibanyoni, J.J.; Tshabalala, P.A.; Tabit, F.T. Food safety knowledge and awareness of food handlers in school feeding programmes in Mpumalanga, South Africa. Food Control 2017, 73, 1397-1406. [CrossRef]

11. Basch, C.H.; Basch, C.E.; Ruggles, K.V.; Hammond, R. Coverage of the Ebola Virus Disease Epidemic on YouTube. Disaster Med. Public Health Prep. 2015, 9, 531-535. [CrossRef]

12. Campos, F.M.; Couto, J.A.; Figueiredo, A.R.; Tóth, I.V.; Rangel, A.O.S.S.; Hogg, T.A. Cell membrane damage induced by phenolic acids on wine lactic acid bacteria. Int. J. Food Microbiol. 2009, 135, 144-151. [CrossRef]

13. Rowell, A.E.; Binkley, M.; Alvarado, C.; Thompson, L.; Burris, S. Influence of food safety training on grocery store employees' performance of food handling practices. Food Policy 2013, 41, 177-183. [CrossRef]

14. Medeiros, L.C.; Hillers, V.N.; Kendall, P.A.; Mason, A. Food safety education: What should we be teaching to consumers? J. Nutr. Educ. Behav. 2001, 33, 108-113. [CrossRef]

15. Abdullah Sani, N.; Siow, O.N. Knowledge, attitudes and practices of food handlers on food safety in food service operations at the UniversitiKebangsaan Malaysia. Food Control 2014, 37, 210-217. [CrossRef]

16. Tóth, A.J.; Bittsánszky, A. A comparison of hygiene standards of serving and cooking kitchens in schools in Hungary. Food Control 2014, 46, 520-524. [CrossRef]

17. Rosset, P.; Cornu, M.; Noël, V.; Morelli, E.; Poumeyrol, G. Time-temperature profiles of chilled ready-to-eat foods in school catering and probabilistic analysis of Listeria monocytogenes growth. Int. J. Food Microbiol. 2004, 96, 49-59. [CrossRef] [PubMed]

18. Cohen, M.H.; Shen, Y.L.; Keegan, P.; Pazdur, R. FDA Drug Approval Summary: Bevacizumab (Avastin ${ }^{\circledR}$ ) as Treatment of Recurrent Glioblastoma Multiforme. Oncologist 2009, 14, 1131-1138. [CrossRef]

19. Nyamari, J. Evaluation of Compliance to Food Saftey Standards Amongst Food Handlers in Selected Hospitals in Kenya. 2013. Available online: http:/ / ir-library.ku.ac.ke (accessed on 12 January 2021).

20. FAO. Food safety risk analysis. A guide for national food safety authorities. FAO Food Nutr Pap. 2006, 87, 43-55. Available online: http:/ / www.fao.org/3/a0822e/a0822e.pdf (accessed on 12 January 2021).

21. Mugenda, O.; Mugenda, A. Research Methods: Quantitative and Qualitative Methods, 1st ed.; ACTS Press: Nairobi, Kenya, 2003; p. 43. ISBN1 9966411070. ISBN2 9789966411075.

22. Ncube, F.; Kanda, A.; Chijokwe, M.; Mabaya, G.; Nyamugure, T. Food safety knowledge, attitudes and practices of restaurant food handlers in a lower-middle-income country. Food Sci. Nutr. 2020, 8, 1677-1687. [CrossRef]

23. Zanin, L.M.; da Cunha, D.T.; de Rosso, V.V.; Capriles, V.D.; Stedefeldt, E. Knowledge, attitudes and practices of food handlers in food safety: An integrative review. In Food Research International; Elsevier Ltd.: Amsterdam, The Netherlands, 2017; Volume 100, pp. 53-62. [CrossRef]

24. Ababio, P.F.; Lovatt, P. A review on food safety and food hygiene studies in Ghana. Food Control 2015, 47, 92-97. [CrossRef]

25. Ko, W.H. The relationship among food safety knowledge, attitudes and self-reported HACCP practices in restaurant employees. Food Control 2013, 29, 192-197. [CrossRef]

26. Altekruse, S.F.; Street, D.A.; Fein, S.B.; Levy, A.S. Consumer knowledge of foodborne microbial hazards and food-handling practices. J. Food Prot. 1996, 59, 287-294. [CrossRef]

27. Da Cunha, M.D.S.B.; Campos Hankins, N.A.; Arruda, S.F. Effect of vitamin A supplementation on iron status in humans: A systematic review and meta-analysis. In Critical Reviews in Food Science and Nutrition; Taylor and Francis Inc.: Oxford, UK, 1767; Volume 59, pp. 1767-1781. [CrossRef]

28. Egan, M.B.; Raats, M.M.; Grubb, S.M.; Eves, A.; Lumbers, M.L.; Dean, M.S.; Adams, M.R. A review of food safety and food hygiene training studies in the commercial sector. Food Control 2007, 18, 1180-1190. [CrossRef]

29. Gould, W. Total Quality Management for the Food Industries; Elsevier: Amsterdam, The Netherlands, 2013.

30. Shinbaum, S.; Crandall, P.G.; O’Bryan, C.A. Evaluating your obligations for employee training according to the Food Safety Modernization Act. Food Control 2016, 60, 12-17. [CrossRef]

31. Tomasevic, I.; Kuzmanović, J.; Andelković, A.; Saračević, M.; Stojanović, M.M.; Djekic, I. The effects of mandatory HACCP implementation on microbiological indicators of process hygiene in meat processing and retail establishments in Serbia. Meat Sci. 2016, 114, 54-57. [CrossRef]

32. Herath, D.; Henson, S. Barriers to HACCP implementation: Evidence from the food processing sector in Ontario, Canada. Agribusiness 2010, 26, 265-279. [CrossRef]

33. Wilcock, L.A.; Ward-Thompson, D.; Kirk, J.M.; Stamatellos, D.; Whitworth, A.; Battersby, C.; Elia, D.; Fuller, G.A.; DiGiorgio, A.; Griffin, M.J.; et al. Isolated starless cores in infrared dark clouds in the Hi-GAL survey. Mon. Not. R. Astron. Soc. 2012, 424, 716-727. [CrossRef] 
34. Thelwell-Reid, M. Food Safety Knowledge and Self-Reported Practices of Food Handlers in Jamaica. Ph.D. Thesis, Walden University, Minneapolis, MN, USA, 2014; p. 204. Available online: https://scholarworks.waldenu.edu/dissertations/75 (accessed on 12 January 2021).

35. Nkhebenyane, J.S.; Lues, R. The knowledge, attitude, and practices of food handlers in central South African hospices. Food Sci. Nutr. 2020, 8, 2598-2607. [CrossRef] [PubMed]

36. Nartey, E.; Owusu, J.; Gamor, E.; Edem Mensah, E. Knowledge and practices of Hygiene of Fresh-Cut Fruit Vendors-A case study of New Juaben Municipality in the Eastern Region of Ghana. Int. J. Technol. Manag. Res. 2017, 2, 36-45.

37. Angelillo, I.F.; Viggiani, N.M.A.; Greco, R.M.; Rito, D. HACCP and Food Hygiene in Hospitals Knowledge, Attitudes, and Practices of Food-Services Staff in Calabria, Italy. Infect. Control. Hosp. Epidemiol. 2001, 22, 363-369. [CrossRef] [PubMed]

38. Giritlioğlu, İ.; Avcıkurt, C. City of Tourist Marketing as a Product of Example Towns and Cities in Turkey. Adryaman Univ. J. Soc. Sci. Inst 2010, 4, 74-89. Available online: https:/ / dergipark.org.tr/tr/pub/adyusbd/issue/1399/16542 (accessed on 12 January 2021).

39. Tokuç, B.; Ekuklu, G.; Berberoğlu, U.; Bilge, E.; Dedeler, H. Knowledge, attitudes and self-reported practices of food service staff regarding food hygiene in Edirne, Turkey. Food Control 2009, 20, 565-568. [CrossRef]

40. Auad, L.I.; Ginani, V.C.; Dos Santos Leandro, E.; Stedefeldt, E.; Habu, S.; Nakano, E. Y.; Costa Santos Nunes, A.; PuppinZandonadi, R. Food trucks: Assessment of an evaluation instrument designed for the prevention of foodborne diseases. Nutrients 2019, 11, 430. [CrossRef]

41. Huang, Y. Applying a "Hypocrisy" Strategy to Improve Food Safety Practises in Restaurants. 2019. Available online: https: / / mospace.umsystem.edu/xmlui/handle/10355/70144 (accessed on 29 January 2021).

42. Kariuki, J.; Orago, S. Food handling practices and the prevalence of food borne pathogens among food handlers in Embu municipality, Kenya. Int. J. Appl. Res. 2017, 3, 697-698.

43. Santos, F.C.; Santos, M.D.; Pacheco, J.M. Social diversity promotes the emergence of cooperation in public goods games. Nature 2008, 454, 213-216. [CrossRef]

44. Nguyen, A.T.L.; Tran, B.X.; Le, H.T.; Le, X.T.T.; Do, K.N.; Do, H.T.; Vu, G.T.; Nguyen, L.H.; Latkin, C.A.; Ho, C.S.H.; et al. Customers' knowledge, attitude, and practices towards food hygiene and safety standards of handlers in food facilities in Hanoi, Vietnam. Int. J. Environ. Res. Public Health 2018, 15, 2101. [CrossRef]

45. Mohd Yusof, A.M.; Rahman, N.A.A.; Haque, M. Knowledge, attitude, and practice toward food poisoning among food handlers and dietetic students in a public university in Malaysia. J. Pharm. Bioallied. Sci. 2018, 10, 232-239. [CrossRef] [PubMed]

46. Abdul-Mutalib, N.A.; Abdul-Rashid, M.F.; Mustafa, S.; Amin-Nordin, S.; Hamat, R.A.; Osman, M. Knowledge, attitude and practices regarding food hygiene and sanitation of food handlers in Kuala Pilah, Malaysia. Food Control 2012, 27, $289-293$. [CrossRef]

47. Adetunji, H.; Baothman, M.; Alserhan, F.; Almunyif, A.; Alsharbe, G.; Samaren, H. Knowledge, Attitude, and Practice (KAP) of Personal Hygiene among Food Handlers in the South Region of Makkah, Saudi Arabia. Int. J. Med. Res. Health Sci. 2018, 7, 96-102.

48. Ko, W.-H. Food Sanitation Knowledge, Attitude, and Behavior for the University Restaurants Employees. Food Nutr. Sci. 2011, 02, 744-750. [CrossRef]

49. Soares-Frazo, S.; Canelas, R.; Cao, Z.; Cea, L.; Chaudhry, H.M.; Die Moran, A.; El Kadi, K.; Ferreira, R.; Cadorniga, I.F.; GonzalezRamirez, N.; et al. Dam-break flows over mobile beds: Experiments and benchmark tests for numerical models. J. Hydraul. Res. 2012, 50, 364-375. [CrossRef] 